\title{
The tunicate Salpa thompsoni ecology in the Southern Ocean II. Proximate and elemental composition
}

Received: 28 July 2004 / Accepted: 16 October 2005

(C) Springer-Verlag 2006

\begin{abstract}
Detailed determination of Salpa thompsoni elemental composition has been carried out on specimens collected in the Eastern Bellingshausen Sea and at the northern edge of the Weddell Gyre during austral autumn (April and May) of 1996 and 2001. More than 170 Antarctic tunicates $S$. thompsoni were analysed to determine wet weight (WW), dry weight (DW), ash-free dry weight (AFDW) and elemental composition $(\mathrm{C}, \mathrm{N}$ content, proteins, carbohydrates and lipids) of different sizes and stages. Dry weight comprised 6.4\% (aggregate form) to $7.7 \%$ (solitary form) of the WW. AFDW amounted to $\sim 44 \%$ of the DW. Carbon and nitrogen contents (Carbon: $17-22 \%$, Nitrogen: $3-5 \%$ of the DW) of both aggregate and solitary forms were found to be high relative to data reported in the literature. Although some unidentified organic compounds are not included in our carbon budget, the findings of this study show higher than previously reported nutritional values of $S$. thompsoni. In spite of this, a shift from a krill-dominated towards a salp-dominated ecosystem would have dramatic consequences for organisms at higher trophic levels.
\end{abstract}

Communicated by O. Kinne, Oldendorf/Luhe

C. D. Dubischar $(\bowtie) \cdot$ E. A. Pakhomov · U. V. Bathmann Alfred Wegener Institute for Polar and Marine Research, Bremerhaven, Germany

E-mail: cdubischar@awi-bremerhaven.de

\section{E. A. Pakhomov}

Department of Earth and Ocean Sciences, University of British Columbia, 6339 Stores Road, V6T 1 Z4 Vancouver, BC, Canada

\section{E. A. Pakhomov}

Zoology Department, Faculty of Science and Technology, University of Fort Hare, Private Bag X1314,

5700 Alice, South Africa

\section{Introduction}

Salpa thompsoni is the most numerous salp species of the Southern Ocean (Foxton 1966). It is also recognized as an important filter feeder in the Southern Ocean (Voronina 1998). Due to their capacity for rapid asexual reproduction (budding), salps are able to form dense swarms, which have been reported to dominate macrozooplankton in different Antarctic regions (Park and Wormuth 1993; Hosie 1994; Nishikawa et al. 1995; Dubischar and Bathmann 1997; Chiba et al. 1998). Salps are microphagous species and their grazing impact may account for $10-100 \%$ of the daily primary production in several regions of the Southern Ocean (Huntley 1989; Dubischar and Bathmann 1997; Perissinotto and $\mathrm{Pa}-$ khomov 1998a). A fine-mesh feeding net enables salps to feed efficiently on a wide range of food particles. Most of this material, however, is removed from the surface layers through fast sinking faecal pellets (Bruland and Silver 1981), thus channelling biogenic carbon out of the surface waters into long-living "pools" in the deep sea (Le Fèvre et al. 1998).

Distribution patterns of $S$. thompsoni were first investigated by Foxton (1966), using samples from expeditions conducted between 1925 and 1951 on the R.V. Discovery. These investigations showed that S. thompsoni has a very patchy distribution. Foxton (1966) considered S. thompsoni to be an Antarctic, coldtemperate species, showing a northern limit of distribution coinciding with the Subtropical Convergence $\left(\sim 45^{\circ} \mathrm{S}\right)$ and a southern limit near the ice edge $\left(\sim 60^{\circ} \mathrm{S}\right)$. During the last 20 years, salps have been reported with increasing frequency in more southerly regions (Kawamura 1986, 1987). Pakhomov et al. (2002) recently updated the map of $S$. thompsoni distribution, compiling the data available from 1980 to 1998. Striking evidence of a southward shift of salp distribution has been found (Pakhomov et al. 2002; Atkinson et al. 2004), but the factors that caused this shift are still under discussion. Have the southern populations reproduced 
successfully or have they been passively transported within warmer water masses? There is some evidence to show that, when salps were found in southern areas, they were restricted to warm water intrusions or layers (e.g. Pakhomov and Fronemann 2004). Chiba et al. (1999) for example found no solitary forms but only small-sized aggregates in high latitudes (off Adélie Land), suggesting that $S$. thompsoni aggregates were transported into the area and not produced therein. It has been suggested that $S$. thompsoni may be close to its physiological limits at high latitudes (Casareto and Nemoto 1986; Chiba et al. 1999).
Since warming of the oceanic current systems south of $45^{\circ} \mathrm{S}$ has been documented (Levitus et al. 2000; Gille 2002), the possibility of the establishment of salp populations further south may become real. Should S. thompsoni survive and propagate in southern areas, it would have a dramatic impact on ecosystem structure and biogeochemistry. The extremely efficient yet sensitive feeding tools of salps may have a strong impact on microplankton biomass and composition, while the fundamentally different elemental and structural body plan of salps may result in significant impacts on sea water chemistry and food acquisition by higher order predators, such as whales and birds. So far, little is

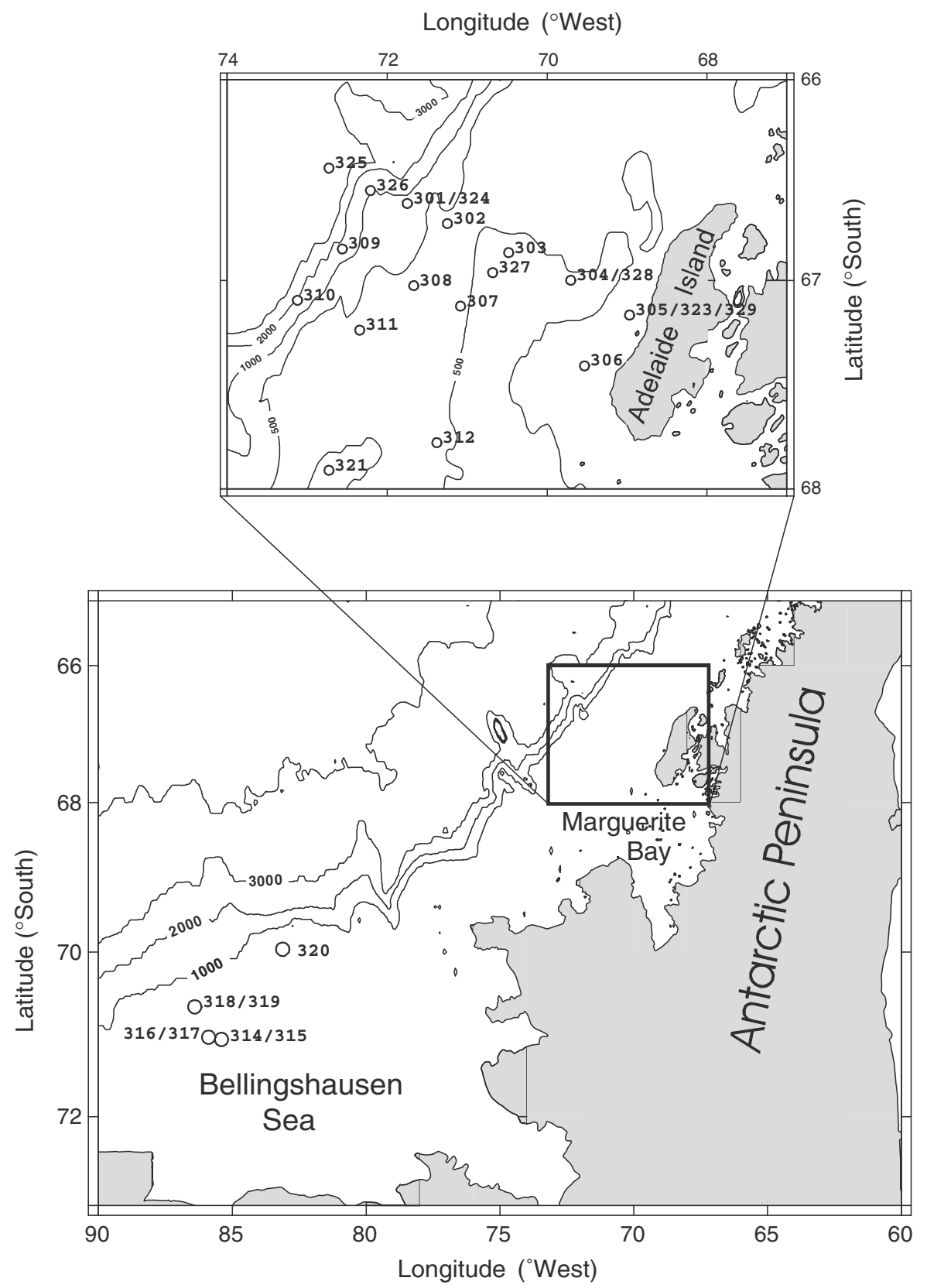

Fig. 1 Investigation area of the expedition ANT XVIII/5b 
known on the value of salps as food as compared to other herbivores such as krill.

We investigated salp abundance and ecology in a high Antarctic area, the Bellingshausen Sea, during April/May 2001 and in the Atlantic sector of the Southern Ocean during April/May 1996 (Fig. 1, Table 1). The results are published in two sister papers: part I concerns biological stages, feeding ecology and faecal pellet production rates (Pakhomov et al. 2005) and part II, the present paper, mainly deals with the proximate and elemental composition and their implications for food web dynamics. Additionally, the results reported here show dry weight (DW), carbon and nitrogen content of different salp stages and sizes and, therefore, can be used to provide estimates of salp standing stocks based on net collections.

\section{Materials and methods}

Samples were mainly taken during the Southern Ocean GLOBEC-cruise ANT XVIII/5b on board RV Polarstern to the Bellingshausen Sea in April/May 2001 (for further information see Pakhomov et al. 2005; Bathmann 2002). The main investigation area was located near Adelaide Island (Fig. 1). Salps were mostly collected at stations 301, 305, 328 and 329 (Pakhomov et al. 2005). In addition, six samples were taken during the expedition ANT XIII/4 on board RV Polarstern to the Atlantic sector of the Southern Ocean in April/May 1996 (Fahrbach 1997). Four stations were sampled along the $0^{\circ}$ meridian, one sample in the middle of the Weddell-Gyre (st. 86) and a sixth (st. 99) close to the Antarctic Peninsula (Table 1).

During expedition ANT XVIII/5b in April/May 2001, salps were caught using an RMT $8+1$ (mesh-size $5 \mathrm{~mm}$ ) and a Bongo net $(300 \mu \mathrm{m})$. For further information concerning the net catches and sample handling see Pakhomov et al. (2005). During the expedition ANT XIII/4 in April/May 1996 salps were collected using a Multinet (mesh size $100 \mu \mathrm{m})$. Salps for analyses of elemental composition were deep-frozen $\left(-80^{\circ} \mathrm{C}\right)$ on board.

In the laboratory, salps were thawed overnight in the refrigerator. The size [total length (TL) and oral-atrial length (OAL)] and biological stage of 173 salps were determined and placed individually into the precombusted and pre-weighted aluminium foil box. After determination of the wet weight (WW) with a Sartorius R200D electro-balance, salps were freeze-dried for $24 \mathrm{~h}$ and DW was determined. About 30 specimens were

Table 1 Stations during the Polarstern-expedition ANT XIII/4 where salps were caught with the Multinet (mesh-size $100 \mu \mathrm{m}$ )

\begin{tabular}{lll}
\hline Station & Position & Date \\
\hline 44 & $60^{\circ} 00.2^{\prime} \mathrm{S} / 0^{\circ} 00.5^{\prime} \mathrm{W}$ & 15.04 .1996 \\
48 & $61^{\circ} 59.9^{\prime} \mathrm{S} / 0^{\circ} 00.0^{\prime} \mathrm{E}$ & 16.04 .1996 \\
50 & $63^{\circ} 00.2^{\prime} \mathrm{S} / 0^{\circ} 00.1^{\prime} \mathrm{E}$ & 17.04 .1996 \\
52 & $64^{\circ} 00.1^{\prime} \mathrm{S} / 0^{\circ} 00.2^{\prime} \mathrm{W}$ & 18.04 .1996 \\
86 & $66^{\circ} 07.9^{\prime} \mathrm{S} / 31^{\circ} 51.4^{\prime} \mathrm{W}$ & 01.05 .1996 \\
99 & $63^{\circ} 44.1^{\prime} \mathrm{S} / 50^{\circ} 50.6^{\prime} \mathrm{W}$ & 07.05 .1996 \\
\hline
\end{tabular}

combusted at $550^{\circ} \mathrm{C}$ for $24 \mathrm{~h}$ to determine the ash-free dry weight (AFDW). Remaining salps were used for biochemical analyses.

Small salps $(\mathrm{TL}<1 \mathrm{~cm})$ were used entire for further analyses. Larger specimens were ground in a small mortar (agate) with a glass pestle to give a homogeneous powder. This enabled us to take sub-samples of these specimens to perform various chemical analyses for the same animal. After freeze-drying and weighing, the animals and the powder were kept in a desiccator.

\section{Biochemical analyses}

Carbon and nitrogen $(\mathrm{C}, \mathrm{N})$, protein, lipid and carbohydrate contents of about 50 organisms of different sizes and stages were measured. Two to four milligram of the homogenised powder (for small salps entire body) have been used. Carbon and nitrogen contents were determined with a Carlo Erba CHN-analyser using acetanilide as a standard. Total lipid content was determined using a Merckotest (use of Vanillin and phosphoric acid). Carbohydrate measurements were carried out after Holland and Gabbott (1971) using a glucose standard and preceded by protein precipitation with $15 \%$ cold TCA. Protein measurements were made following a modified version of the Lowry Assay (Lowry et al. 1951, http://www.hood.edu/academic/biology/protein.htm), using bovine serum albuminum as a standard.

\section{Statistics}

Analyses of variance were performed to detect significant differences between the means of the aggregate and the solitary forms. Using the program Sigma-Stat, a one-way ANOVA was calculated and the Holm-Sidak Test was applied for multiple comparisons.

\section{Results}

Total length/oral atrial length

Since some authors use TL while others use OAL, we plotted TL as a function of OAL to enable conversions from one value to the other (Fig. 2). For the solitary forms, TL (corresponding to length A in Foxton 1966) was only slightly higher than the OAL (corresponding to length B in Foxton 1966). For the aggregate forms, differences were larger due to the appendices at both sides of their body (Fig. 2).

Wet weight/dry weight/C/N-content

Wet weight of the measured salps varied between 13.5 and $1752.2 \mathrm{mg} /$ Ind (aggregate forms) and between 112.9 and $5456.4 \mathrm{mg} /$ Ind (solitary forms) (Fig. 3).

Dry weight ranged from 0.91 to $103.1 \mathrm{mg} / \mathrm{Ind}$ (aggregate forms) and from 6.8 to $361.7 \mathrm{mg} / \mathrm{Ind}$ (solitary 
Fig. 2 Total length of aggregate and solitary forms of $S$. thompsoni compared to their oral-atrial length $(O A L)$

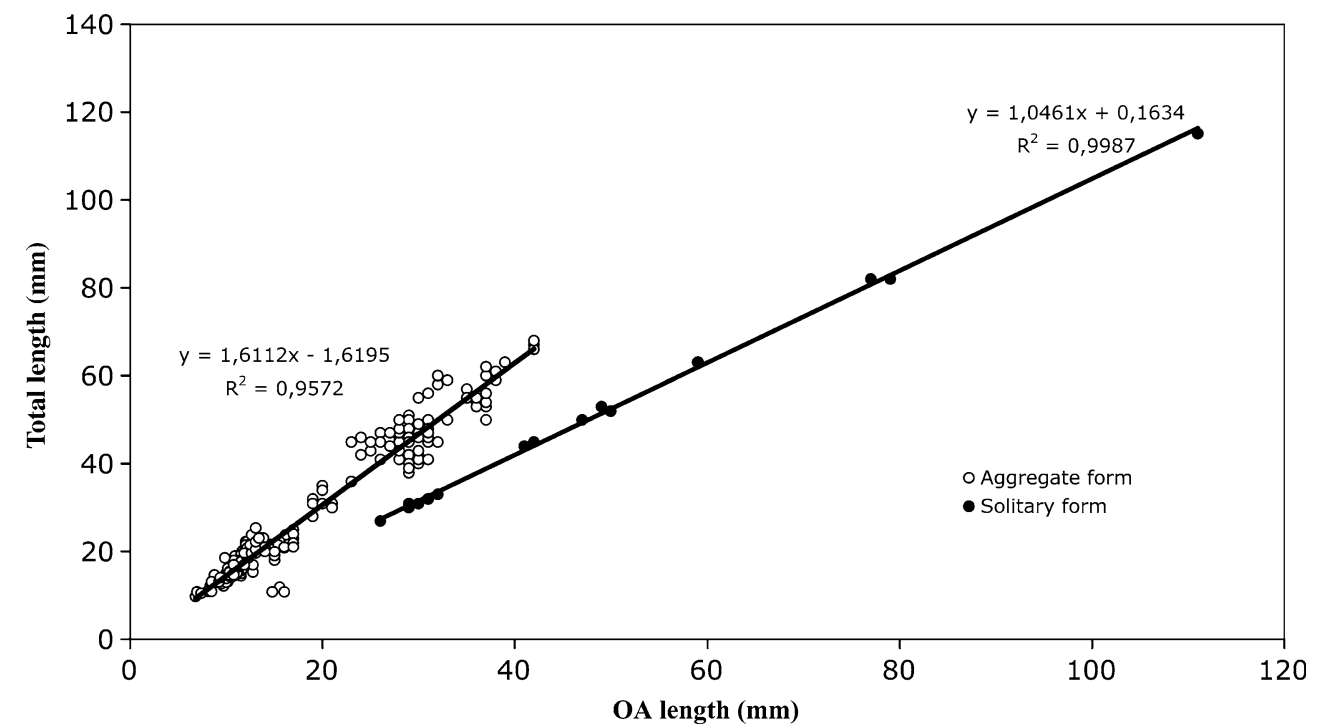

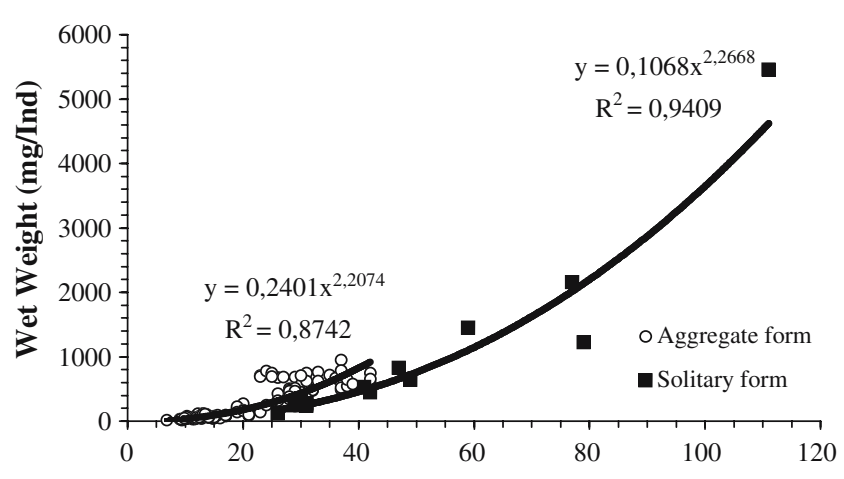
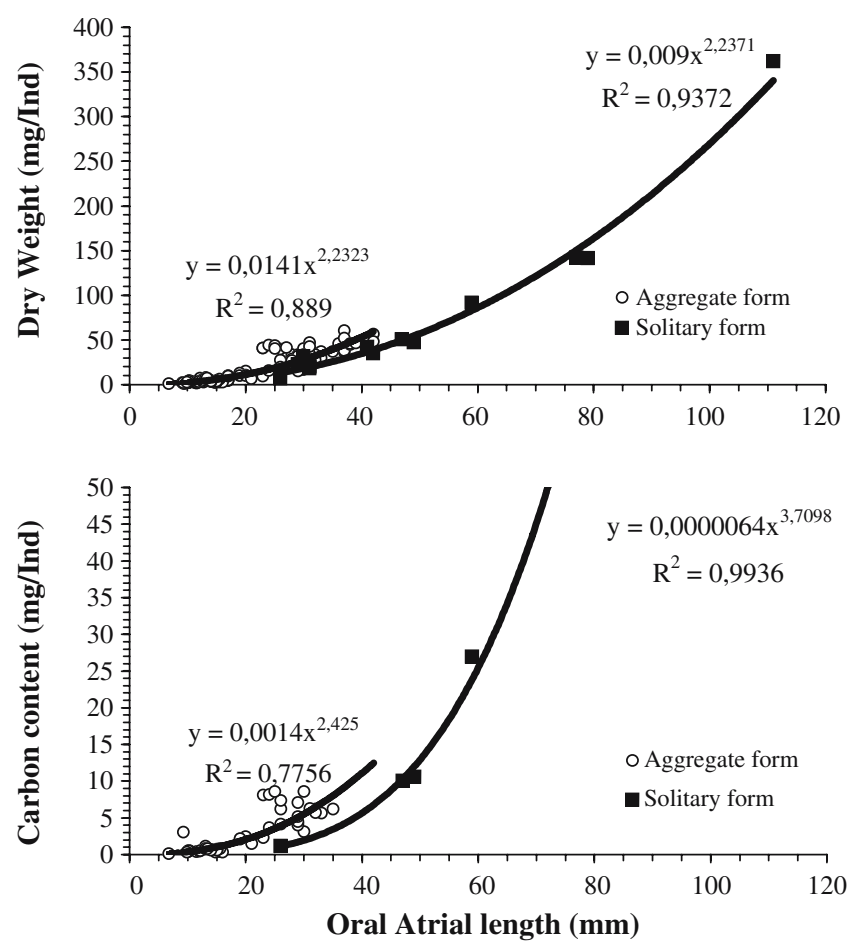

Fig. 3 Wet weight $(W W)$, dry weight $(D W)$, and carbon content of of $S$. thompsoni as a function of oral atrial length $(O A L)$ forms, Fig. 3). On average, DW accounted for $6.4 \pm 0.9 \%$ (aggregate forms) to $7.7 \pm 1.4 \%$ (solitary forms) of the WW (Table 2). Differences in DW between both stages are statistically significant (Table 2).

Carbon content was found to be $17.4 \%( \pm 4.1)$ of the DW for aggregate and $22.5 \%( \pm 5.5)$ for solitary forms. These differences in carbon content between both forms were also statistically confirmed (Table 2 ).

Biochemical compounds/elemental composition (proteins, total lipids, carbohydrates)

The largest portions of biochemical compounds were proteins and lipids, ranging from 4 to $8 \%$ of the DW (Table 3). Solitary forms contained slightly higher percentages of proteins and lipids compared to the aggregate forms, whereas the percentage of carbohydrates was very similar. Protein content weight was 0.07 $3.73 \mathrm{mg} /$ Ind and $1.53-18.5 \mathrm{mg}$ in aggregate and solitary forms, respectively (Fig. 4). Total lipid weight ranged from 0.1 to $2.82 \mathrm{mg} /$ Ind in aggregate forms and from

Table 2 Wet weight (WW), dry weight (DW), ash-free dry weight (AFDW), carbon (C) and nitrogen (N) content of different stages of Salpa thompsoni, expressed as percentage of the different values

\begin{tabular}{lrlrll}
\hline & $n$ & $\begin{array}{l}\text { Aggregate } \\
\text { form }\end{array}$ & $n$ & $\begin{array}{l}\text { Solitary } \\
\text { form }\end{array}$ & $P$ \\
\hline$\% \mathrm{DW} / \mathrm{WW}$ & 158 & $6.4 \pm 0.9$ & 15 & $7.7 \pm 1.4$ & $<0.001$ \\
$\%$ AFDW/DW & 28 & $44.0 \pm 8.5$ & 0 & - & - \\
$\% \mathrm{C} / \mathrm{DW}$ & 50 & $17.4 \pm 4.1$ & 4 & $22.3 \pm 5.3$ & $<0.05$ \\
$\% \mathrm{~N} / \mathrm{DW}$ & 50 & $3.53 \pm 1.1$ & 4 & $4.93 \pm 1.2$ & $<0.05$ \\
C/N & 50 & $5.07 \pm 0.8$ & 4 & $4.53 \pm 0.1$ & $\mathrm{NS}$ \\
$\% \mathrm{C} / \mathrm{AFDW}$ & 1 & 42.4 & 0 & - & - \\
$\% \mathrm{~N} / \mathrm{AFDW}$ & 1 & 9.22 & 0 & - & - \\
\hline
\end{tabular}

$n$ Number of salps measured 
Table 3 Protein, carbohydrate and lipid content of Salpa thompsoni, expressed as percentage of the dry weight (DW)

\begin{tabular}{lllrll}
\hline & $n$ & $\begin{array}{l}\text { Aggregate } \\
\text { form }\end{array}$ & $n$ & $\begin{array}{l}\text { Solitary } \\
\text { form }\end{array}$ & $P$ \\
\hline Protein content (\% DW) & 37 & $4.4 \pm 1.6$ & 11 & $7.7 \pm 1.8$ & $<0.001$ \\
Carbohydrates (\% DW) & 21 & $0.9 \pm 0.8$ & 8 & $0.8 \pm 0.3$ & NS \\
Lipids (\% DW) & 33 & $5.7 \pm 4.4$ & 11 & $6.8 \pm 2.3$ & NS \\
\hline
\end{tabular}

$n$ Number of salps measured, $N S$ Not significant

1.11 to $30.76 \mathrm{mg} /$ Ind in solitaries (Fig. 4). Carbohydrates amounted to $0.01-0.41 \mathrm{mg} / \mathrm{Ind}$ and 0.14 $2.32 \mathrm{mg} /$ Ind in aggregates and solitaries, respectively (Fig. 4).
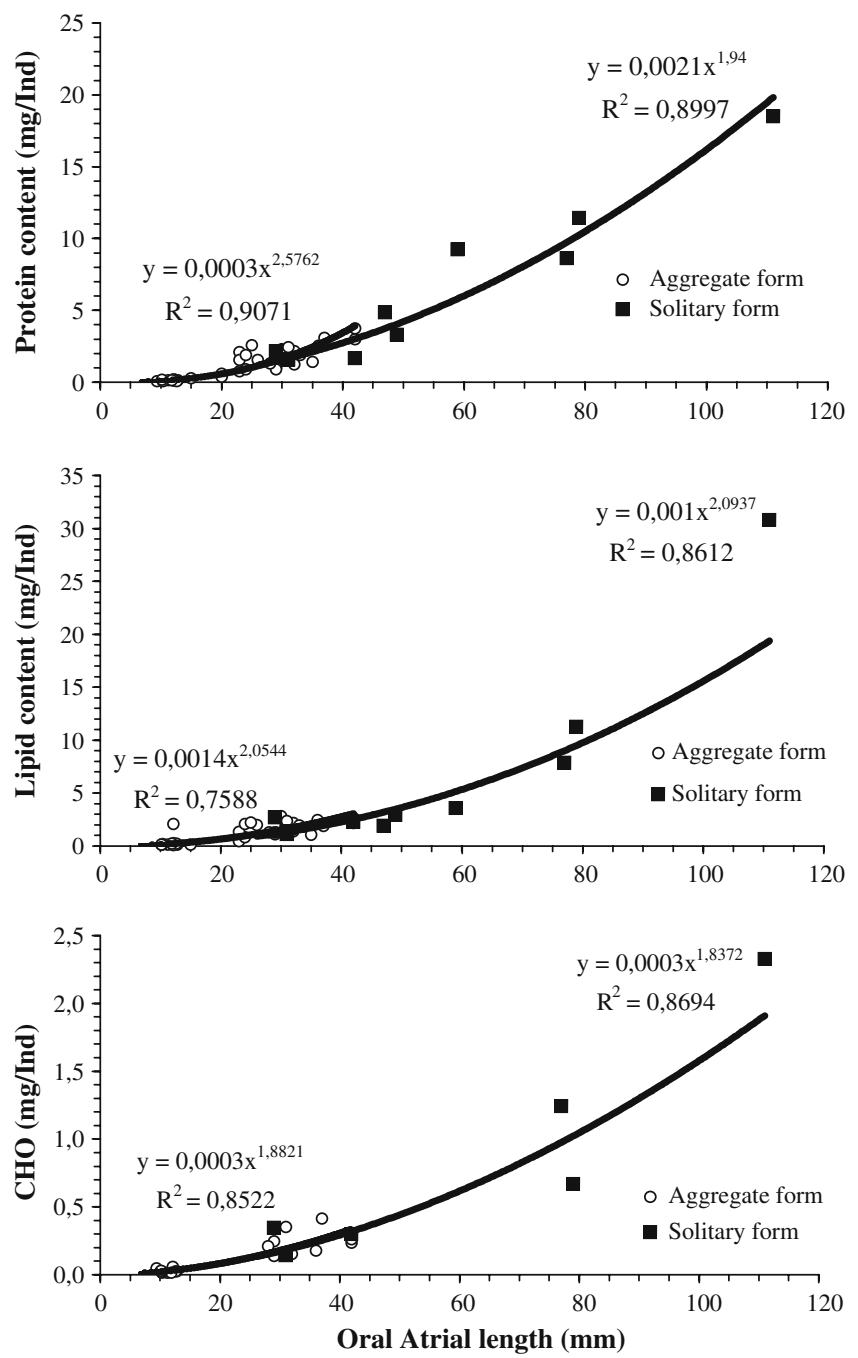

Fig. 4 Elemental composition (proteins, lipids and carbohydrates) of $S$. thompsoni as a function of oral atrial length $(O A L)$
Large embryos

At station 328 , we sampled surprisingly large salp embryos (ca. 3-3.5 cm), detached from their mother salp but still connected to their placenta and eleoplast (see photo in Pakhomov et al. 2005). Their values for DW, carbon etc. showed no differences compared to the other stages of same size $(P>0.05)$.

\section{Discussion}

To our knowledge, few data on elemental composition of $S$. thompsoni has been published (Ikeda and Mitchell 1982; Ikeda and Bruce 1986; Huntley et al. 1989; Donnelly et al. 1994; Iguchi and Ikeda 2004). We, therefore, also compared our data with measurements carried out on other species from different regions of the world oceans (Madin et al. 1981; Heron et al. 1988; Clarke et al. 1992).

In gelatinous zooplankton, an important source of variability in biochemical composition has been ascribed to the gut contents (Clarke et al. 1992). In the present study, although we measured a large number of salps $(>150)$, variability in parameters measured was negligible and as a consequence the standard deviations of parameters appeared to be small. This indicates that sources of variability such as differences in gut fullness were negligible.

It is noteworthy, that no significant differences were found in elemental composition between salps collected during the expeditions in April/May 1996 and 2001, despite these being collected in different regions of the Southern Ocean. The data obtained for specimens from both cruises were, therefore, pooled.

\section{Wet weight/dry weight/AFDW}

Determination of DW of gelatinous zooplankton is known to be difficult. Gelatinous tissue tends to retain a significant amount of water after drying by traditional techniques. This "water of hydration"-phenomenon probably occurs because of the high content of gelforming components, e.g. polymeric polysaccharides and proteins in salp bodies, which retains water very strongly (see discussion in Madin et al. 1981; Clarke et al. 1992). This leads to an overestimation of the salp DW.

Generally, the DW of salps ranges between 4 and $8 \%$ of the WW (Table 4). While most of the authors dealing with the composition of salps used traditional oven drying techniques, we used the freeze-drying technique to determine the DW. Clarke et al. (1992) investigated a variety of gelatinous species and determined DW by drying at $60^{\circ}$, for up to $155 \mathrm{~h}$. According to their findings, DW of the Southern Ocean species Salpa fusiformis accounted for $4.7 \%$ of the WW (Table 4). Huntley et al. (1989) also used the $60^{\circ} \mathrm{C}$ oven drying 
Table 4 Comparison of our study with recent studies on salp composition

See legend of Table 2 for abbreviations

\begin{tabular}{lllll}
\hline Species & DW as \% WW & AFDW \% DW & C \% DW & References \\
\hline Salpa thompsoni & 7 & 44.0 & $17-22$ & This study \\
& $3.9-4.0$ & - & $4.2-4.7$ & Ikeda and Bruce (1986) \\
& $\sim 4$ & 27 & 3.4 & Huntley et al. (1989) \\
Salpa fusiformis & $\sim 4$ & 29.1 & $\sim 10$ & Reinke (1987) \\
Thalia democratica & 8.7 & 33.5 & $11.9 \pm 2.0$ & Clarke et al. (1992) \\
Salpa thompsoni & 3.8 & 46.5 & 18 & Heron et al. (1988) \\
& $3.1-3.5$ & $28.4-29.7$ & 4.7 & Ikeda and Mitchell (1982) \\
Pegea confoederata, & - & 26.6 & $5.1-6.0$ & Iguchi and Ikeda (2004) \\
Salpa cylindrical, & & & 7.8 & Madin et al. (1981) \\
Salpa maxima & & & & \\
\hline
\end{tabular}

technique and arrived at similar (4\%) values for S. thompsoni. Heron et al. (1988) used higher temperatures $\left(105^{\circ} \mathrm{C}\right)$ for up to $72 \mathrm{~h}$ and found the DW of Thalia democratica to be $8 \%$ of the WW (Table 4 ).

Schindler et al. (1971) compared freeze-drying with oven drying at up to $100^{\circ} \mathrm{C}$ and found no significant difference in the weights obtained by two methods. In the Southern Ocean, only Ikeda and Bruce (1986) and Iguchi and Ikeda (2004) used freeze-drying to determine DW of $S$. thompsoni and found that they accounted for only $\sim 4 \%$ of the WW, very similar to the values i.e. obtained by Clarke et al. (1992) for S. fusiformis and Huntley et al. (1989) for S. thompsoni. Our values 7\% (Tables 2,4) were higher than most other measurements. We can only speculate that this might be a seasonal effect, since the other measurements were conducted during austral spring (Ikeda and Bruce 1986) and austral summer (Clarke et al. 1992; Iguchi and Ikeda 2004), thus earlier in the year compared to our study.

Ash-content was very high and accounted for about $56 \%$ of the DW (AFDW of $44 \pm 8 \%$ DW). This high ash-content is characteristic of gelatinous zooplankton and some authors found even higher percentages (Huntley et al. 1989: 73\%; Clarke et al. 1992: 66.4\%; Donnelly et al. 1994: 55-70\%). Other zooplankton species, such as copepods, show much lower values [e.g. Calanoides acutus ca. 8\%, Calanus propinquus ca. 10\% (Donnelly et al. 1994)]. The high percentage of AFDW indicates further difficulties of the "water of hydration" effect, which is not driven off by freeze-drying or oven drying, but removed during ashing.

Donnelly et al. (1994) found seasonal variations in the ash content of $S$. thompsoni. While it accounted for $70 \%$ of the DW in summer, it was significantly lower in winter $(56 \% \mathrm{DW})$. This is consistent with our data $(56 \%)$, taken in late autumn.

Compared to aggregates, solitary forms of S. thompsoni showed slightly higher values of DW as percentage of the WW and carbon and nitrogen content as percentage of the DW (Table 2). The elevated content in organic material was mainly due to a higher content of proteins and, to a lesser degree, lipids (Tables 2, 3). This fact is also reflected in a slightly lower $\mathrm{C} / \mathrm{N}$ ratio of the solitary forms (Table 2). Madin et al. (1981) compared their $\mathrm{C} / \mathrm{N}$-measurements with other literature data and found a similar pattern.

\section{Carbon/nitrogen-content}

Our values were higher than in most of other recent studies on carbon content of salp organisms (Table 4), not only when expressed as percentage of the DW (17-20\%), but also in terms of $\mathrm{mg} \mathrm{C}$ per Ind (Fig. 3). Presently, only measurements of Heron et al. (1988) for $T$. democratica were in the same order of magnitude.

Most other zooplankton species have a much higher percentage of carbon per DW: e.g. Euphausia superba 42.6-47.1\% (Ikeda and Bruce 1986), copepods close to $50 \%$ DW (Mizdalski 1988; Donnelly et al. 1994). It is difficult to believe that our values are elevated due to methodological faults. It is indeed noteworthy that AFDW, carbon and lipid (see below) content are all in good agreement showing consistently higher levels than in most other salp species. In the absence of detailed seasonal measurements, we cannot discount the possibility that the high values obtained in this study could be explained by seasonal variability.

\section{Protein/lipid/carbohydrates}

The AFDW should roughly correspond to the organic compounds of the salp body, i.e. the sum of proteins, lipids and carbohydrates. In our case, the sum of these compounds, expressed as "total organics" (TO after Madin et al. 1981), accounted for $25-35 \%$ of the AFDW, thus explaining only a small portion of the AFDW. Similarly, other authors reported comparably low values ranging from 19 to $51 \%$ (Madin et al. 1981). The missing part is considered to be at least partly "residual" or "bound" water, which is not driven off by drying but lost while ashing (Madin et al. 1981). Certainly, some chemical compounds of the salp bodies such as nucleic acids and other smaller molecules cannot be detected with the techniques mentioned above, but typically, they are minor fractions of the organics compounds. Nevertheless, a large proportion of the AFDW 
remains unaccounted for. For comparison, the sum of ash, proteins, lipids, carbohydrates and chitin in crustacean zooplankton typically accounts for $90-95 \%$ of the DW (Clarke et al. 1992). Madin et al. (1981) investigated North Atlantic salp species and found the proteins to be the major contributor $(\sim 82 \%)$ to the TO. This corresponded to $6.6 \%$ of the DW. This value is substantially higher than obtained in our study, e.g. $40-50 \%$ of the TO for aggregates and solitaries, respectively. This corresponded to $\sim 4.4 \%$ of the DW (Table 3). Much higher protein contribution to the TO measured by Madin et al. (1981) likely resulted from lower lipid content in the salps when compared to our values.

On average, the lipid content in the North Atlantic species accounted for $7.6 \%$ of the TO (Madin et al. 1981), corresponding to $\sim 0.6 \%$ of the DW. Our findings showed much higher values, e.g. $45-52 \%$ of the TO, corresponding to $5.7-6.8 \%$ of the DW. Hagen (1988) found lower lipid contents (only $2.3-3.3 \%$ of the DW). This could be a seasonal effect since Hagen's measurements for $S$. thompsoni were obtained from specimens collected during austral summer in the southern Weddell Gyre. Certainly more investigations are needed to detect potential seasonal changes in salp elemental composition.

Carbohydrate concentrations in salps are very low and generally account for about $1 \%$ of the DW: e.g. $0.8-$ $0.9 \%$ of the DW (our data), $0.8 \%$ (Madin et al. 1981) and $1.3 \%$ (Clarke et al. 1992). This is surprising, because the tunic of tunicates such as ascidians consists mainly of an extracellular product, composed of protein and polysaccharides (Smith and Dehnel 1971).

What are the missing components?

As mentioned above, the sum of proteins, lipids, carbohydrates and ash explain only about two thirds of the salps DW. Also, the missing components might partly be due to residual water, which is not driven off by oven drying, thus inflating the DW estimates, but lost during ashing, leading to an underestimate of the ash content. However, a substantial number of organic compounds may not have been detected by our techniques. Below we discuss possible scenarios for the "missing components".

The measured $\mathrm{C}$ accounted for $17.4 \% \mathrm{DW}$ (aggregate forms). Clarke et al. (1992) calculated the average fraction of carbon in organic matter being 0.55-0.6. If we apply this factor to our carbon measurements, our measured $\mathrm{C}$ would correspond to an amount of total organics of $29-32 \%$ of the DW, whereas our measurements detected only TO of about $11 \%$ of the DW. This indicates that the "missing third" of the AFDW is not only "residual water" but must also consist of organic compounds. The low $\mathrm{C} / \mathrm{N}$-ratio excludes compounds without nitrogen, such as carbohydrates and lipids. Therefore, the unidentified OM likely consists of proteins or glycoproteins, which could be highly cross-linked leading to their ineffective extraction and detection. Furthermore, it is generally assumed that the $\mathrm{N}$ content of proteins accounts for $16-17 \%$. If we calculate the protein content of $S$. thompsoni on the basis of our $\mathrm{N}$ measurements and using these conversion factors, the protein content of $S$. thompsoni would increase to $20-22 \%$ of the DW, which is fivefold higher than the value we measured (4.4\%). Overall, from both $\mathrm{C}$ and $\mathrm{N}$ scenarios it appears that some groups of proteins have not been detected by our measurements.

In summary, although some organic compounds were likely not detected by our methods, our findings show higher nutritional values of $S$. thompsoni than previously reported. Furthermore, the seasonal variability in salp elemental composition clearly warrants further investigation.

\section{Role of salps in the Antarctic ecosystem}

A shift of salp distribution to more southerly regions and an expulsion of krill would have a dramatic impact on the structure of Antarctic ecosystems. Although results of this study revealed a higher nutrition value of salps than previously assumed, it still remains unclear whether salps will be able to meet energetic demands of higher trophic level predators in the absence of krill; the consumption of gelatinous species, such as salps, by fish has in fact been reported several times (Duhamel and Hureau 1985; Kashkina 1986; Pakhomov 1993; Mianzan et al. 2001). Furthermore, some birds may consume salps (see review in Pakhomov et al. 2002). However, it has been shown that because of warming of watery food up to the endothermic body temperature of about $40^{\circ} \mathrm{C}$, a higher energetic demand will result (4.17 Joules per $g$ water for $1^{\circ} \mathrm{C}$ ) than the chemical energy stored in salps (Wilson and Culik 1991). Antarctic krill also have a relative high water content $(80 \%)$. However, its high content of proteins and lipids, 65.1 and $14.2 \%$ of the DW (Grantham 1977), compared to only 5.2 and $6.0 \%$ of the DW of salps (Table 3), would result in a calorific value per unit of mass much higher than in salps. This makes krill an important and preferred food source for most of endotherms in the Antarctic. We therefore speculate that a large-scale switch of a krill-dominated system to a salp-dominated system (Atkinson et al. 2004) may not only alter regional carbon flux, but most probably will have a dramatic impact on feeding conditions of higher trophic levels and lead to a decrease in top predator populations.

Acknowledgements We wish to thank the captain, officers and crew of the RV "Polarstern" for their skilful help throughout both cruises. Special thanks are due to Eberhard Fahrbach (chief scientist during the ANT XIII/4-cruise) who greatly supported the work of a small biology group in the middle of a large group of oceanographers with lots of tasks. We also wish to thank Christian Hamm, Richard Crawford and two anonymous reviewers for carefully reading the manuscript and their very helpful comments. This work was partly funded by a grant of the Alexander von Humboldt-Stiftung for E.A.P. 


\section{References}

Atkinson A, Siegel V, Pakhomov EA, Rothery P (2004) Long-term decline in krill stock and increase in salps within the Southern Ocean. Nature 432:100-103

Bathmann UV (2002) The expedition ANTARKTIS XVIII/5b of the research vessel "Polarstern" in 2001. Rep Polar Mar Res 407:98

Bitterlich G, Gnaiger E (1984) Phytoplanktivorous or omnivorous fish? Digestibility of zooplankton by silvercarp, Hypophthalmichthys molitrix (Val.). Aquaculture 40:261-263

Bruland KW, Silver MW (1981) Sinking rates of Faecal pellets from gelatinous zooplankton (Salps, Pteropods, Doliolids). Mar Biol 63:295-300

Casareto BE, Nemoto T (1986) Salps of the Southern Ocean (Australian sector) during the 1983-84 summer, with special reference to the species Salpa thompsoni. Mem Nat Inst Polar Res 40:221-239

Chiba S, Ishimaru T, Hosie GW, Wright SW (1999) Population structure change of Salpa thompsoni from austral mid-summer to autumn. Polar Biol 22:341-349

Clarke A, Holmes LJ, Gore DJ (1992) Proximate and compositionof gelatinous zooplankton from the Southern Ocean. J Exp Biol Ecol 155:55-68

Donnelly J, Torres JJ, Hopkins TL (1994) Chemical composition of Antarctic zooplankton during austral fall and winter. Polar Biol 14:171-183

Dubischar CD, Bathmann UV (1997) Grazing impact of copepods and salps on phytoplankton in the Atlantic sector of the Southern Ocean. Deep Sea Res II 49:415-433

Duhamel G, Hureau JC (1985) The role of zooplankton in the diets of certain Sub-Antarctic marine fish. In: Siegfried WR, Condy PR, Laws RM (eds) The 4th SCAR symposium on Antarctic biology, Wilderness (South Africa), 12-16 September

Fahrbach E, Gerdes D (1997) The expedition ANT XIII/4-5 of the research vessel "Polarstern" 1996. Rep Polar Mar Res 239:126

Foxton P (1966) The distribution and life-history of Salpa thompsoni Foxton with observations on a related species, Salpa gerlachei Foxton. Discov Rep 34:1-116

Gille ST (2002) Warming of the Southern Ocean since the 1950s. Science 295:1275-1277

Grantham GJ (1977) The utilization of krill. Southern Ocean Fisheries Survey Programme, Food and Agriculture organization of the united nations, United Nations development programme, Rome, 4

Hagen W (1988) On the significance of lipids in Antarctic zooplankton. Rep Polar Res 49:129

Heron AC, McWilliam PS, Dal Pont G (1988) Length-weight relation in the salp Thalia democratica and potential of salps as a source of food. Mar Ecol Prog Ser 42:125-132

Holland DL, Gabbott PA (1971) A micro-analytical scheme for the determination of proteins, carbohydrate, lipid and RNA levels in marine invertebrate larvae. J Mar Biol Assoc UK 51:659-668

Hosie GW (1994) Multivariate analyses of the macrozooplankton community and euphausiid larvae ecology in the Prydz Bay region, Antarctica. ANARE Rep 137:1-209

Huntley ME, Sykes PF, Marin V (1989) Biometry and trophodynamics of Salpa thompsoni Foxton (Tunicata, Thaliacea) near the Antarctic Peninsula in austral summer, 1983-1984. Polar Biol 10:59-70

Iguchi N, Ikeda T (2004) Metabolism and elemental composition of aggregate and solitary forms of Salpa thompsoni (Tunicata: Tahlaicea) in waters off the Antarctic Peninsula during austral summer 1999. J Plankt Res 26:1025-1037

Ikeda T, Bruce B (1986) Metabolic activity and chemical composition of krill and other zooplankton from Prydz bay, Antarctica, during early summer (November-December). Mar Biol 92:545-555
Ikeda T, Mitchell AW (1982) Oxygen uptake, ammonia excretion and phosphate excretion by krill and other Antarctic zooplankton in relation to their body size and chemical composition. Mar Biol 71:283-298

Kashkina AA (1986) Feeding of fishes on salps (Tunicata: Thaliacea). J Ichthyol 26:57-64

Kawamura A (1986) Has marine Antarctic ecosystems changed?-A tentative comparison of present and past macrozooplankton abundances. Mem Nat Inst Polar Res 40:197-211

Kawamura A (1987) Two series of macrozooplankton catches with the $\mathrm{H} 70 \mathrm{~V}$ net in the Indian sector of the Antarctic Ocean. In: Proceedings of the NIPR symposium on polar boil, vol 1, pp 84-89

Le Fèvre J, Legendre L, Rivkin RB (1998) Fluxes of organic carbon in the Southern Ocean: roles of large microphagous zooplankton. J Mar Syst 17:35-345

Levitus S, Antonov JI, Boyer TP, Stephens C (2000) Warming of the World Ocean. Science 287:2225-2229

Lowry OH, Rosebrough JN, Farr AL, Randall RJ (1951) Protein measurements with the Folin reagent. J Biol Chem 193:265-275

Madin LP, Cetta CM, McAlister VL (1981) Elemental and biochemical composition of salps (Tunicata: Thaliacea). Mar Biol 63:217-226

Mianzan H, Pajaro M, Alvarez Colombo G, Madirolas A (2001) Feeding on survival-food: gelatinous plankton as a source of food for anchovies. Hydrobiologia 451:45-53

Mizdalski E (1988) Weight and length data of zooplankton in the Weddell Sea in austral spring 1986 (ANT V/3). Reports on Polar Research 55, $72 \mathrm{pp}$

Nishikawa J, Naganobu M, Ichii T, Ishii $H$, Terazaki $M$, Kawaguchi K (1995) Distribution of salps near the South Shetland Islands during austral summer, 1990-1991 with special reference to krill distribution. Polar Biol 15:31-39

Pakhomov EA (1993) Feeding habitats and estimate of ration of gray notothenia, Notothenia squamifrons squamifrons Norman, on the $\mathrm{Ob}$ and Lena tablemounts (Indian Ocean sector of Antarctica). J Ichthyol 33(9):57-71

Pakhomov EA, Fronemann PW (2004) Zooplankton dynamics in the eastern Atlantic sector of the Southern Ocean during the austral summer 1997/1998 - Part 2: Grazing impact. Deep Sea Res II 51:2617-2631

Pakhomov EA, Fronemann PW, Perissinotto R (2002) Salp/krill interactions in the Southern Ocean: spatial segregation and implications for the carbon flux. Deep-Sea Res II 49:1881-1907

Pakhomov EA, Dubischar CD, Strass V, Brichta M, Bathmann UV (2005) The tunicate Salpa thompsoni ecology in the Southern Ocean. I. Distribution, biomass, demography and feeding ecophysiology (submitted)

Park C, Wormuth JH (1993) Distribution of Antarctic zooplankton 1989, and 1990. Polar Biol 13:215-225

Perissinotto R, Pakhomov EA (1998a) Contributions of salps to carbon flux of marginal ice zone of the Lazarev Sea, Southern Ocean. Mar Biol 131:25-32

Reinke M (1987) On the feeding and locomotory physiology of Salpa thompsoni and Salpa fusiformis. Berichte Polarforsch 36:89

Schindler DW, Clark AS, Gray JR (1971) Seasonal calorific values of freshwater zooplankton, as determined with a Phillipson Bomb Calorimeter modified for small samples. J Fish Res Bd Can 28:559-564

Smith MJ, Dehnel PA (1971) The composition of tunic from four species of ascidians. Comp Biochem Physiol 40:615-622

Voronina NM (1998) Comparative abundance and distribution of major filter-feeders in the Antarctic pelagic zone. J Mar Syst 17:375-390

Wilson RP, Culik BM (1991) The cost of a hot meal: facultative specific dynamic action may ensure temperature homeostasis in post-ingestive endotherms. Comp Biochem Physiol 100:151-154 